\title{
Knowing for controlling: ecological effects of invasive vertebrates in Tierra del Fuego
}

\author{
Conocer para controlar: efectos ecológicos de vertebrados invasores en Tierra del Fuego
}

\author{
CLAUDIA A. SILVA ${ }^{1 *} \&$ BÁRBARA SAAVEDRA ${ }^{2}$
}

\author{
${ }^{1}$ Facultad de Ciencias, Universidad de Chile, Santiago, Chile \\ 2 Wildlife Conservation Society, of icina en Chile, Santiago, Chile \\ * e-mail for correspondence: csilvap@gmail.com
}

\begin{abstract}
The Tierra del Fuego (TDF) archipelago is recognized as part o the last places on Earth that may still be considered wild. However, this condition may be threatened by the large number of invasive species present on the archipelago. These species can have significant effects on the ecology of the invaded ecosystems, at the genetic as well as at population, community and ecosystem levels. The aim of this study is to, by a bibliographic review, systematize existing information on the ecological impacts these species would be having on the TDF archipelago and detect information gaps in order to orient future research and effective management programs on these species. We restricted our review to vertebrate, non-marine invaders. We determined which species have invaded TDF, described their impacts on the archipelago and evaluated their potential impacts; this last issue was determined by reviewing some of the impacts these species have had in other geographic areas. Our findings indicate that at least nine vertebrate species (Salmo trutta, Salvelinus fontinalis, Oncorhynchus mykiss, Castor canadensis, Ondatra zibethicus, Oryctolagus cuniculus, Pseudalopex griseus, Mustela vison and Sus scrofa) have wild populations established away from human settlements in TDF. There is some scientific evidence on ecological impacts on the area for only five of these invaders, with the American beaver (Castor canadensis) being the species monopolizing the greatest number of studies. These results contrast with the recognition, both in TDF and worldwide, of the potential of most of these species to cause significant ecological impacts, which makes it unlikely that the lack of verified impacts on TDF reflects an absence of significant effects of these invaders on the archipelago. We suggest that future research should focus on determining population density and distribution of these and other (i.e., feral species) invasive vertebrates, as well as their impacts mainly on freshwater systems, vegetation, soil and ground nesting birds. Regarding management, interactions between invaders must be considered. Whether the TDF archipelago is especially vulnerable to biological invasions remains to be proven, however, future introductions should be carefully weighed.
\end{abstract}

Key words: impacts, introduced, exotic, Chile, Argentina.

\section{RESUMEN}

El archipiélago de Tierra del Fuego (TDF) ha sido reconocido como parte de los últimos lugares del planeta que aún pueden considerarse silvestres. Sin embargo, esta condición puede verse amenazada por el gran número de especies invasoras presentes en el archipiélago. Estas especies pueden tener efectos significativos sobre la ecología del sistema invadido, tanto a nivel genético como poblacional, comunitario y ecosistémico. El objetivo de este estudio es, mediante una revisión bibliográfica, sistematizar la información acerca del impacto ecológico que estas especies tienen sobre el archipiélago de TDF y detectar vacíos de información, para orientar la investigación futura y planes efectivos de manejo de estas especies. Restringimos nuestra revisión a invasores vertebrados no marinos. Determinamos cuáles especies han invadido TDF, describimos sus impactos sobre el archipiélago y evaluamos sus impactos potenciales, ésto último mendiante una revisión de los impactos que estas especies han tenido en otras zonas geográficas. Nuestros resultados indican que, al menos, nueve especies de vertebrados (Salmo trutta, Salvelinus fontinalis, Oncorhynchus mykiss, Castor canadensis, Ondatra zibethicus, Oryctolagus cuniculus, Pseudalopex griseus, Mustela vison y Sus scrofa) cuentan con poblaciones silvestres establecidas, lejanas a zonas pobladas en TDF. Solo para cinco de éstas existe evidencia científica sobre sus impactos ecológicos en el área, siendo el castor americano (Castor canadensis) la especie que acapara la mayor cantidad de estudios. Estos resultados contrastan con el reconocimiento, tanto en TDF como a nivel mundial, del potencial de estas especies de provocar impactos ecológicos significativos, que hace poco probable que la falta de impactos comprobados en TDF se deba a una 
ausencia de efectos significativos de estos invasores en el archipiélago. Sugerimos que la investigación futura se aboque a determinar la densidad y distribución poblacional de estos y otros (i.e., especies asilvestradas o baguales) vertebrados introducidos, así como sus impactos principalmente en los sistemas de agua dulce, la vegetación, el suelo y las aves que nidifican sobre él. Respecto al manejo, las interacciones entre invasores deben ser consideradas. Si es que el archipiélago de Tierra del Fuego es especialmente vulnerable a las invasiones biológicas debe aún ser probado, sin embargo, introducciones futuras debieran ser sopesadas cuidadosamente.

Palabras clave: impactos, introducidas, exóticas, Chile, Argentina.

\section{INTRODUCTION}

Tierra del Fuego has been recognized as part of one the last places on Earth that may still be considered wild, given its huge land surface area still conserving great extensions of intact natural vegetation and large vertebrate assemblages, along with a low human population density (Mittermeier et al. 2002). However, these peculiar conditions may be threatened by the large number of invasive species introduced into the area by humans (Lizarralde \& Escobar 2000, Jaksic et al. 2002, Anderson et al. 2006b). Although only a fraction of the species introduced, either intentionally or accidentally, into a new habitat get to establish there permanently (Williamson \& Fitter 1996), those that do can have serious effects on the ecology of the ecosystems invaded, which can be expressed at the genetic as well as at population, community and ecosystem levels. For example invasive species are recognized to be the second cause (after loss of habitat) explaining the threatened state of native species in the United States of America (Wilcove et al. 1998). Invaders are capable of significantly altering ecosystem processes, including nutrient cycling, productivity patterns, disturbance regimes and the hydrological, geomorphology or atmospheric components of the ecosystem structure (Mack \& D'Antonio 1998, Mack et al. 2000, Dukes \& Mooney 2004). Biological invasions also have evolutionary consequences, such as adaptative responses or extinctions (Mooney \& Cleland 2001, Lee 2002, Olden et al. 2004, Schlaepfer et al. 2005). Together, these effects may alter the natural ecology and, therefore, persistence of native systems.

The biota of the Tierra del Fuego archipelago (hereinafter TDF) might be especially vulnerable to the effects of invasive species since their probability of establishment and the magnitude of their impacts seem to be higher on islands (Simberloff 1995, Fritts \& Rodda 1998, Wilcove et al. 1998, Krajick 2005), although departures from this pattern are common (e.g., Sol 2000). The enhanced vulnerability of islands to biological invasions seems to be related to the complete absence of some functional groups (e.g., large predators), derived from isolation (Simberloff 1995).

The published works on the impacts of invasive species on the ecology of TDF are few (e.g., Jaksic \& Yáñez 1983a, Lizarralde 1993, Anderson et al. 2006a), and they have focused on a small subset of all invaders present. On the other hand, some management programmes for them have been developed (Iriarte et al. 2005) but their effectiveness has been limited so far, since adequate knowledge on the invaders and their impacts is needed for these programmes to be successful (Groves 2003). Within this scenario, this work aims to systematize existing information on the impacts of the invasive species present on the TDF archipelago and detect information gaps, to orient future research in order to develop effective management programmes for these invaders.

\section{The Tierra del Fuego archipelago}

The Tierra del Fuego archipelago is located at the southernmost tip of the American continent, between $52^{\circ}$ and $56^{\circ}$ South Latitude. The largest island, Isla Grande $\left(48.000 \mathrm{~km}^{2}\right)$, is separated from the continent by the Strait of Magellan (4-30 km wide; Fig. 1). There are other important islands in terms of size such as Isla Hoste $\left(4.800 \mathrm{~km}^{2}\right)$ and Isla Navarino $\left(2.800 \mathrm{~km}^{2}\right)$, along with about 200 small islands composed from a single rock to a few square kilometers of land (Moore 1983). Politically, one sector is on the Chilean territory and another on Argentina. The borderline between these two countries runs along Isla Grande, set by a meridian rather than by any natural geographic barriers (Martinic 1998). Population 
density is low, especially in the Chilean side of Isla Grande (1.1 inhabitants $\mathrm{km}^{-2}$, INE 2003). Vegetation on the archipelago is heterogeneous and can be categorized into four major zones: Patagonian Steppe, Deciduous Forest, Evergreen Forest and Magellanic Moorland. A fifth zone of Alpine Vegetation can be found at high elevations (Moore 1983).

\section{Bibliographic review}

We conducted a search by keywords on two databases (ISI Web of Science and SCOPUS) for references on invasive vertebrate species on TDF. Available reports of governmental agencies, non-indexed Chilean scientific journals and a list of literature on Chilean invasive vertebrate species that covers from 1841 to present (Center for Advanced Studies in Ecology and Biodiversity, CASEB) were also consulted. The information was reviewed to determine which invaders can be found today on TDF and the ecological impact they are having on its natural systems. We complement this information with a description of potential effects of these species, based on their impacts on other geographic areas and putative, but yet unconfirmed, impacts on TDF. Information of impacts on other geographic areas was selected based on availability and not necessarily on the similarity of these areas to TDF. Nonetheless, when the impacts on these areas depended on specific conditions not found in TDF, they were not considered.

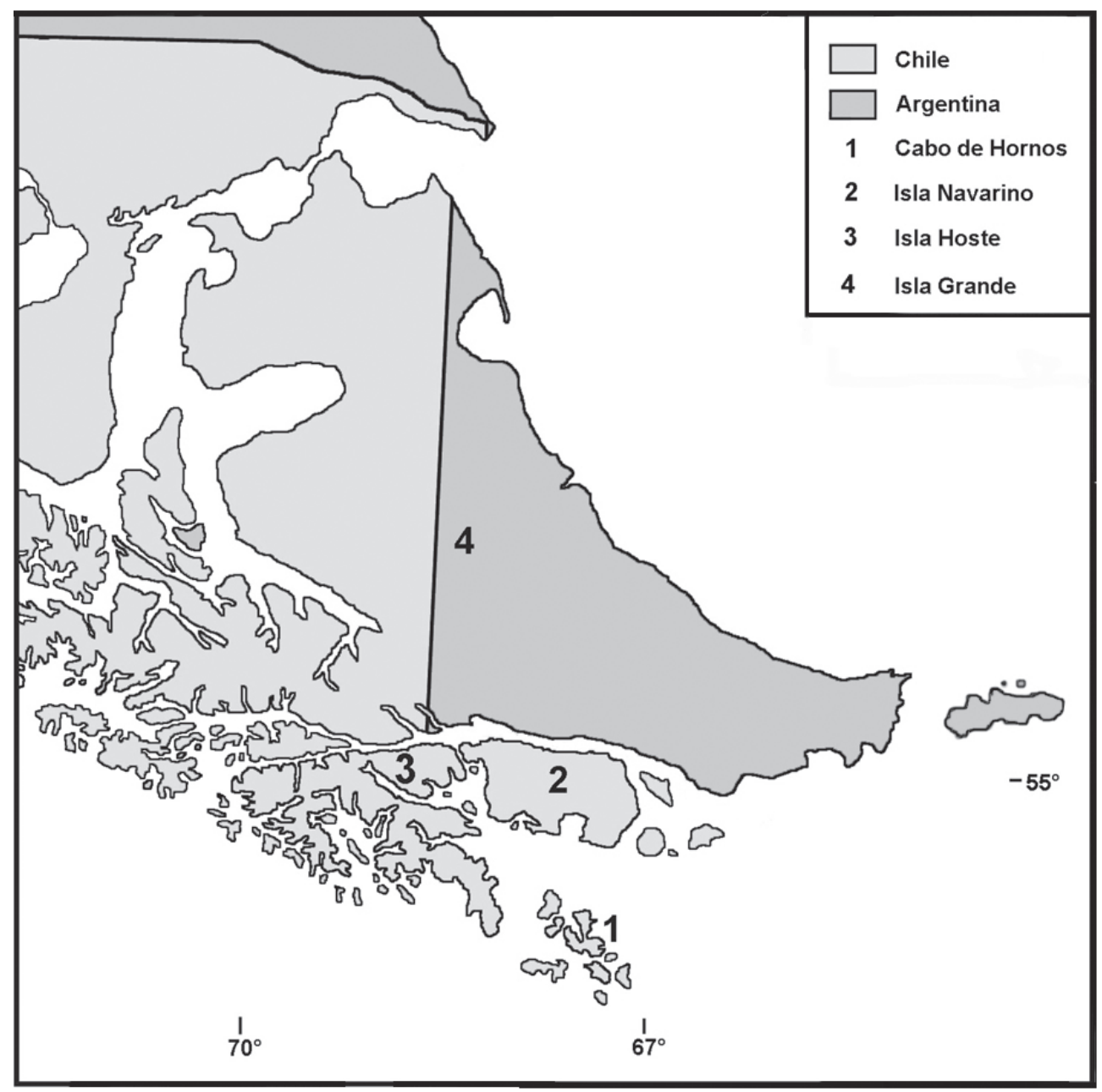

Fig. 1: Map of the Tierra del Fuego archipelago. The islands mentioned in the text are indicated by numbers.

Mapa del archipiélago de Tierra del Fuego. Las islas mencionadas en el texto se indican con números. 
This review is restricted to invasive, nonmarine vertebrate species whose presence as wildlife on TDF is confirmed by scientific or governmental data, since introduced species that remain exclusively related to human populations (e.g., house mouse Mus musculus Linnaeus, 1758) do not seem to have a relevant impact on the native systems of TDF (Anderson et al. 2006b).

\section{Vertebrate invaders of the Tierra del Fuego ar- chipelago}

Of the 24 exotic terrestrial vertebrate species found in Chile (Jaksic 1998, Iriarte et al. 2005), at least five have wild, human-independent populations on TDF: the American beaver (Castor canadensis Kuhl, 1820), the muskrat (Ondatra zibethicus Linnaeus, 1766), the American mink (Mustela vison Schreber, 1777), the European rabbit (Oryctolagus cuniculus Linnaeus, 1758) and the wild pig (Sus scrofa Linnaeus, 1758). Some of them continue to colonize new territories, and have even become established on the continental mainland (Sieldfeld \& Venegas 1980, Jaksic \& Yáñez 1983a, Lizarralde 1993, Lizarralde et al. 1996, Jaksic 1998, Skewes et al. 1999, Jaksic et al. 2002, Rozzi \& Sherriffs 2003, Anderson et al. 2006a, 2006b). The number of invaders present on the archipelago is increased if freshwater vertebrates are considered as well; at least three species have colonized some of its main water bodies: the rainbow trout (Oncorhynchus mykiss Walbaum, 1792), the brown trout (Salmo trutta Linnaeus, 1758) and the river trout (Salvelinus fontinalis Mitchill, 1814) (Vila et al. 1999, Pascual et al. 2002, Anderson et al. 2006b). Finally, one last vertebrate can be included on the list of invaders: the chilla fox (Pseudalopex griseus Gray, 1837) which is a native species, but only to continental land and not the TDF archipelago (Jaksic \& Yañez 1983a).

Below we give a description, in taxonomic order, of the current situation and the verified and potential effects of these invaders on the ecology of TDF.

\section{Salmonids (Salmonidae)}

Current situation: On Isla Grande, the most abundant species of the icthyofauna are $O$. mykiss and S. trutta, a pattern observed in its four main limnic systems (Vila et al. 1999). Another salmonid species present on the archipelago is S. fontinalis (Pascual et al. 2002, Anderson et al. 2006b). Additionally, salmonid farming has risen in past years and, consequently, so have reports of escape from aquaculture areas (Pascual et al. 2002).

Effects on Tierra del Fuego: no available information.

Potential effects: Vila et al. (1999) suggested that, even though the presence of only one native fish species, Galaxias maculatus (Jenyns, 1842), is coherent with the extreme weather, geological age and short development of river systems on TDF, it cannot be excluded that invasive salmonids are affecting native fish population and abundance and even be causing instances of local extinction. In support of this idea, to the north of TDF, in two lakes with no presence of salmonids, Soto et al. (2006) found the largest populations of Aplochiton zebra (Jenyns, 1842) and Galaxias platei (Steindachner, 1898), two native species also present on the Argentinean side of TDF (Cussac et al. 2004); and density of salmonids and native fish show a negative correlation in southern Chile (Soto et al. 2006). Some of the mechanisms that could explain these trends include competition for habitat and food, as well as direct predation (Vila et al. 1999). In fact, predation by salmonids on $G$. platei has been confirmed in Chilean Patagonia, as well as competition for benthic invertebrates ${ }^{1}$.

The most commonly reported ecological effects of salmonids in other geographic areas relate, coherently, to the exclusion or reduction of native fish populations (Nakano et al. 1998, Penczak et al. 1999, Morita et al. 2004, Peterson et al. 2004), and include some relatives of the native Galaxias fish of TDF (McIntosh \& Townsend 1994, Allibone 1999). The mechanisms are those suggested by Vila et al. (1999). It is important to point out that a given salmonid species can also affect another salmonid (e.g., Peterson et al. 2004).

1 HABIT E, JJ ORTIZ, P PIEDRA \& N ORTIZ (2007) Patrones comunitarios de la fauna íctica nativa e introducida en sistemas lacustres y fluviales de la Patagonia. III Reunión Binacinal de Ecología, La Serena, Chile. CD de Resúmenes. 
The effect of salmonids has also been studied on aquatic invertebrates. For example, it has been demonstrated that differences in predating strategies between $S$. trutta and native fish results in changes in the antipredatory behavior of some Ephemeroptera species (McIntosh \& Townsend 1994). Also, some of the most remarkable effects of this invader occur through trophic cascades, when its predation on aquatic invertebrates results in changes on algal biomass (Flecker \& Townsend 1994, Huryn 1998). These trophic-cascading effects also occur in the case of $O$. mykiss, but through a different mechanism: when native fish are displaced by invasive $O$. mykiss from their original dietary resource; terrestrial insects that fall into the rivers, they resort to feeding on benthic insects. This results in increased algal biomass by reduction of invertebrate grazers, but also on decreased abundance of spiders on river banks, caused by the lower number of adult insects emerging from the river (Baxter et al. 2004).

The consequences of the salmonid invasions may cause the local extinction of key invertebrate species, so the restoration of the system is therefore only partial, even years after the extirpation of invaders (McNaught et al. 1999). Nevertheless, it can be speculated that the recovery of the system is possible (Townsend 1996).

\section{Beaver (Castor canadensis Kuhl, 1820)}

Current situation: the beaver population on the Chilean side of Isla Grande and Isla Navarino is estimated to be 60.000 individuals with a density of 1.03 colonies $\mathrm{km}^{-1}$ (Skewes et al. 2006). On the Argentinean side, the density can reach up to 5.8 colonies $\mathrm{km}^{-1}$ (Lizarralde 1993). These densities are high even when compared to the original habitat of the species (Lizarralde 1993, Skewes et al. 1999). The great colonizing capacity of beavers has favored its arrival to other islands comprising this archipelago (Sieldfeld \& Venegas 1981, Skewes et al. 1999, Anderson et al. 2006a). Despite the extensive use this mammal makes of woody material, on TDF beavers have even colonized areas where only herbaceous material exists. The only sites the beavers have been unable to colonize are those located 600-800 $\mathrm{m}$ above sea level and rocky, unvegetated sites (Skewes et al. 1999).
In recent years they have even reached the continental landmass (Skewes et al. 2006).

Effects on Tierra del Fuego: the action of the beaver has caused changes in the original course and characteristics of native hydrological systems, by land flooding and sedimentation (Skewes et al. 1999). As for the chemical properties of water, significant changes in the concentrations of organic carbon, phosphorous and nitrogen occur as a result of the activity of this rodent (Lizarralde et al. 1996).

One of the most evident impacts that result from beaver invasion can be observed in riparian vegetation, which they use both as food and construction material. On Isla Navarino, beavers have significantly reduced arboreal cover up to $30 \mathrm{~m}$ from river banks (Anderson et al. 2006a). On TDF, they show a preference to cut trees of a smaller diameter $(2.5-5 \mathrm{~cm})$ and of reduced height $(40-60 \mathrm{~cm})$, impeding tree regeneration (Sieldfeld \& Venegas 1980, Skewes et al. 1999). Foraging is highly selective but wide in terms of vegetal strata; they forage on trees (e.g., Nothofagus betuloides (Mirb) Blume, N. pumilio (P et. E) Krasser, N. antarctica (G. Forst.) Oerst., and Drymis winteri Forst., as well as on shrubs (e.g., Pernettya mucronata (L.f.) Gaudich. ex Spreng., Berberis ilicifolia (Lf. 1781) and Chilliotrichum diffusum (Forster f.) O. Kuntze) and even on forbs (Sieldfeld \& Venegas 1980, Lizarralde 1993). Added to the direct effect of foraging, vegetation is also affected by dam construction, a process through which beavers flood adjacent land, with the consequent death, by anoxia, of the terrestrial vegetation present within the beaver pond (Sieldfeld \& Venegas 1980). The magnitude of these impacts varies depending on the topography of the flooded area; dams built on a flat area form significantly larger ponds than those built on sites with steep slopes (Lizarralde 1993). On the other hand, erosion is more severe in these steeply sloped areas (Skewes et al. 1999).

Even after beavers abandon their dams, the ecological effects of their activity continue. The dam eventually ruptures and vegetation starts to recolonize the formerly flooded land. The soil is now highly fertile, and so a meadow dominated by grass and sedge species develops instead of the original riparian vegetal community (Anderson et al. 2006a, MartínezPastur et al. 2006). Thus, species composition 
is altered and richness is increased, partly due to invasion of exotic plants (Anderson et al. 2006a). Vegetal biomass and cover are also affected, and mostly increase in comparison to primary forest. This new vegetal community persists even 20 years after dam abandonment and it can extend between 15 and $95 \mathrm{~m}$ from the river bank. The forests of TDF appear incapable of supporting long-term beaver impact, since no recovery of the original forest community has been observed after this period of time (Martínez-Pastur et al. 2006).

The activity of beavers also affects vertebrates. Ponds become a source of aquatic invertebrates, resulting in increased density of birds that rely on this resource (Sieldfeld \& Venegas 1980). One of these birds is the Magellanic woodpecker (Campephilus magellanicus King, 1827) (Vergara \& Schlatter 2004), a species whose populations are considered in a vulnerable state of conservation in that area (Glade 1988).

Potential effects: in North America, the original land of the beaver, the impact of this species on the physical and chemical nature of aquatic ecosystems, and their consequences on ecosystem processes such as decomposition of organic matter, have been studied. The main impacts owe to the quick transformation of a terrestrial system into an aquatic one by ground flooding and of a lotic into a lentic system by damming. The accumulation of sediment is significant during these processes (e.g., 2.000$6.500 \mathrm{~m}^{3}$ for a dam regarded as small) (Naiman et al. 1986). In addition, the reduction in water velocity diminishes the rate of supply of nutrients, resulting in decreased rate of organic matter decomposition. Pooled water favors anaerobic decomposition and therefore production of methane increases by up to fifteen times (Naiman et al. 1986). The new aquatic environment affects population of invertebrates, including emerging insects and benthic and free-swimming invertebrates such as cladocerans (Nummi 1992).

Interactions between beavers and other invasive species can be expected in TDF. For example, the use of active beaver lodges by muskrats, another invader present on TDF has been reported in North America (McKinstry et al. 1997). At the same time, salmonids will also be affected due to the transformation of the aquatic habitat. Dominance over native fish by salmonids invading Patagonia is higher in lotic systems ${ }^{1}$, wich are interrupted by beaver dams.

\section{Muskrat (Ondatra zibethicus Linnaeus, 1766)}

Current situation: the muskrat was originally introduced from North America to the Isla Grande of TDF (Jaksic et al. 2002), but has now colonized other islands of the archipelago, such as Isla Hoste and Isla Navarino (Anderson et al. 2006b).

Effects on Tierra del Fuego: muskrats are common prey of invasive minks ${ }^{1}$.

Potential effects: the muskrat inhabits aquatic systems where it builds its lodges using surrounding vegetation, which is also its main source of food. Lodges may remain active for several months, whereafter they may be reconstructed or abandoned, depending on the condition of the remaining vegetation (Lynch et al. 1947, Connors et al. 2000). Additionally, muskrats dig on the muddy bottom, disturbing the sediment, to a depth of up to $50 \mathrm{~cm}$ (Lynch et al. 1947). The size of the lodges can reach up $3 \mathrm{~m}^{2}$ of surface area. A vegetal community develops atop them dominated by different species than those found prior to colonization by muskrats (Kangas \& Hannan 1985). The lodges are characterized by accelerating microbial activity and decomposition relative to adjacent areas (Wainscott et al. 1990). Nitrogen mineralization and nitrification are increased around lodges, probably because digging and trampling by muskrats aerates the soil (Connors et al. 2000). As with beavers, muskrat activity affects some of the chemical properties of water, such as $\mathrm{pH}$, temperature, conductivity and dissolved oxygen (De Szalay \& Cassidy 2001). However, the most significant impacts of muskrats occur on aquatic vegetation. At low population densities, the rat creates open water patches within the dense vegetation matrix, but at high population densities it may completely transform high-density areas into open water systems, which must then be abandoned for lack of vegetation (Lynch et al. 1947). Selective foraging results in an altered taxonomic composition of the vegetal community, as well as decreased biomass and diversity, shifts in species dominance and even local extinction of plant species. The magnitude of the impacts will depend on the dominance of the vegetal species preferred by rats (Lynch et al. 1947, Smirnov \& Tretyakov 1998, Connors et al. 2000). 
Effects of vertebrate invaders at population, community and ecosystem levels in Tierra del Fuego. Population level effects are sub-classified as trophic effects (the taxon predates on native biota or is predated by it), facilitation (of other invaders) and effects on abundance of native populations.

Community level effects are sub-classified as changes in species richness and composition or competition with other species. Ecosystem level effects are sub-classified as changes in nutrient cycles, soil or sediments and water flow. A taxon or group of taxa is marked with a $\mathrm{P}$ for potential effects and an $\mathrm{X}$ for confirmed effects on Tierra del Fuego

Efectos de vertebrados invasores en Tierra del Fuego en los niveles de población, comunidad y ecosistema. Los efectos en el nivel poblacional están subdivididos en efectos tróficos (la especie depreda algún componente de la biota nativa o es depredada por él), facilitación (de otros invasores) y efectos en la abundancia de poblaciones nativas. Los efectos en el nivel comunitario están subdivididos en cambios sobre la riqueza, la abundancia y competencia con otras especies. Los efectos en el nivel ecosistémico están subdivididos en cambios en los ciclos de nutrientes, el suelo o el sedimento y el flujo de agua. Un taxón o grupo de taxa es marcado con un $\mathrm{P}$ para efectos potenciales y una X para efectos comprobados en Tierra del Fuego

\begin{tabular}{|c|c|c|c|c|c|c|c|c|c|}
\hline \multirow[t]{3}{*}{ Taxa } & \multicolumn{9}{|c|}{ Level of effect } \\
\hline & \multicolumn{3}{|c|}{ Population } & \multicolumn{3}{|c|}{ Community } & \multicolumn{3}{|c|}{ Ecosystem } \\
\hline & $\begin{array}{c}\text { Trophic } \\
\text { effect }\end{array}$ & Facilitation & $\overline{\text { Abundance }}$ & Richness & Competition & $\overline{\text { Composition }}$ & $\begin{array}{l}\text { Nutrient } \\
\text { cycles }\end{array}$ & $\begin{array}{c}\text { Soil or } \\
\text { sediment }\end{array}$ & $\begin{array}{l}\text { Water } \\
\text { flow }\end{array}$ \\
\hline Salmonids & $\mathrm{P}$ & & $\mathrm{P}$ & $\mathrm{P}$ & $\mathrm{P}$ & $\mathrm{P}$ & & & \\
\hline Beaver & $\mathrm{X}$ & $\mathrm{X} / \mathrm{P}$ & $\mathrm{X}$ & $\mathrm{X}$ & & $X$ & $\mathrm{X} / \mathrm{P}$ & $\mathrm{X}$ & $X$ \\
\hline Muskrat & $X$ & $\mathrm{P}$ & $\mathrm{P}$ & $\mathrm{P}$ & & $\mathrm{P}$ & $\mathrm{P}$ & $\mathrm{P}$ & \\
\hline Rabbit & $\mathrm{X} / \mathrm{P}$ & & $\mathrm{P}$ & $\mathrm{P}$ & & $\mathrm{P}$ & & $\mathrm{P}$ & \\
\hline Chilla fox & $\mathrm{X} / \mathrm{P}$ & & $\mathrm{P}$ & & & & & & \\
\hline Mink & $X$ & & $\mathrm{X}$ & $\mathrm{P}$ & $\mathrm{P}$ & & & & \\
\hline Wild pig & $\mathrm{P}$ & & $\mathrm{P}$ & $\mathrm{P}$ & & $\mathrm{P}$ & $\mathrm{P}$ & $\mathrm{P}$ & \\
\hline
\end{tabular}

Aquatic invertebrate communities are affected by the new physical, chemical and biotic conditions imposed by muskrats. Taxonomic composition is altered on and around lodges, as is their trophic structure; abundance of gathering collectors increases while scrapers become less abundant than in dense vegetation zones (De Szalay \& Cassidy 2001).

Regarding impacts on vertebrates, some birds are attracted to the new habitat created by muskrats but others see their original habitat destroyed (Lynch et al. 1947). Additionally, being an important component of the diet of the American mink, at least on Isla Navarino ${ }^{2}$, they might have facilitated the successful establishment of this invader on the archipelago.

2 SCHUETTLER E, M GAÑAN, S MCGEHEE, R ROZZI \& K JAX (2007) Impacto del visón norteamericano (Mustela vison) una especies carnívora invasora recientemente registrada en Isla Navarino, Chile. III Reunión Binacional de Ecología, La Serena, Chile. CD de Resúmenes.
European rabbit (Oryctolagus cuniculus Linnaeus, 1758)

Current situation: the European rabbit is restricted today to human-inhabited islands of TDF (Anderson et al. 2006b). They were once very abundant on the archipelago but were controlled by the introduction of the Myxoma virus in 1954 (Jaksic \& Yáñez 1983).

Effects on Tierra del Fuego: the European rabbit is an important component of the diet of the native and endangered (Glade 1988) culpeo fox (Pseudalopex culpaeus, Molina, 1782; lycoides sub-species) (Jaksic et al. 1983).

Potential effects. The ecological effects of the rabbit are not unknown matter in Chile, vegetation being the most impacted component of the system. Rabbits are mainly responsible for the pattern of herbaceous distribution in the matorral of central Chile, since their foraging habits differ from those of native herbivores and prevent herb seedling establishment in unprotected areas (i.e., under bushes) (Jaksic \& Fuentes 1980). In addition, 
rabbits also inhibit bush regeneration through the consumption of their seedlings, thus impeding secondary succession (Fuentes et al. 1983). The loss of vegetal cover promotes soil erosion by rain (Ferriere et al. 1983). Taxonomic composition of the vegetal community is affected, favoring the persistence of species not consumed by rabbits (Fuentes et al. 1983, North et al. 1994). On the other hand, the rabbit has become an important component of the diet of native predators such as canids, mustelids and birds of prey (Ferriere et al. 1983, Jaksic \& Yáñez 1983, Jaksic et al. 1983, Simonetti 1986).

\section{Chilla fox (Pseudalopex griseus Gray, 1837)}

Current situation: the chilla fox is native to continental Chile and Argentina, but was introduced to the Isla Grande of TDF and its current distribution is restricted to this area (Jaksic \& Yáñez 1983, Anderson et al. 2006b).

Effects on Tierra del Fuego: reproduction of the ruddy-headed goose (Chloephaga rubidiceps Sclater, 1860), a migratory bird whose Fueguian population is endangered (Glade 1988), is restricted to areas protected from predation by this fox (Madsen et al. 2003). This has determined management actions focusing on the localized control of fox populations (Blanco et al. 2001).

The chilla fox was introduced to TDF to control rabbit populations, yet, its level of consumption is low when compared to the native culpeo fox. Additionally, the high reproductive rate of rabbits make it unlikely for either of these two fox species to control rabbit populations in a significant way (Jaksic \& Yáñez 1983b), nor is there evidence to assume competition between these two foxes (Jaksic et al. 2002).

Potential effects: birds are an important component in the diet of the chilla fox (Jaksic et al. 1983), so other species like the upland goose (Chloephaga picta Gmelin, 1789) might be affected by predation (Madsen et al. 2003). Whether the magnitude of the predatory impact on this and other birds species is of concern remains to be further investigated. Chilla foxes also predate on invertebrates and small mammals (Jaksic et al. 1983).
American mink (Mustela vison Schreber, 1777)

Current situation: the mink is a carnivore that was introduced to Isla Grande over 50 years ago (Jaksic et al. 2002) and, like beavers and muskrats, it has also colonized other islands of the archipelago, such as Isla Navarino (Rozzi \& Sherriffs 2003, Anderson et al. 2006b).

Effects on Tierra del Fuego: birds are a common component of the diet of minks on Isla Navarino. It predates on fledgelings as well as on adults and significantly reduces the reproductive success of solitary species, such as the flightless steamer duck (Tachyeres pteneres J. R. Förster, 1844). They also predate on mammals, including invasive muskrats ${ }^{2}$.

Potential effects: one of the most common ecological effects arising from mink invasion affects bird reproduction (e.g., Craik 1997, Ferreras \& McDonald 1999, Clode \& MacDonald 2002, Nordström \& Korpimäki 2004). This owes to direct predation by minks of eggs and chicks, as well as on adult individuals, significantly reducing reproductive success of the predated species (e.g., Ferreras \& MacDonald 2004). Minks have highly variable diet that may also include rodents, fish and shellfish so its impacts are not restricted to birds alone (Dunstone \& Birks 1987, Medina 1997).

Competition between minks and other mustelids, like the endangered (Glade 1988) river otter (Lontra provocax Thomas, 1908) has not been directly addressed on the archipelago, but minks have shown not to affect otter populations where they coexist elsewhere (e.g., Medina 1997, Aued et al. 2003). On the other hand, high mink population densities can be found along the coastline of TDF (Anderson et al. 2006b), where they are able to predate on the intertidal invertebrate community (Delibes et al. 2004). Whether this could negatively impact the native and also endangered (Glade 1988) marine otter (Lontra felina Molina, 1782) is unknown.

The presence of mink may be favorable for controlling the population of rabbits and muskrats, since they can be relevant to its diet, both in $\mathrm{TDF}^{2}$ as elsewhere (Arnold \& Fritzell 1987, Dunstone \& Birks 1987). Available evidence from other latitudes supports this possibility, since invasive minks might be responsible for important population declines 
of another aquatic rodent, the water vole (Arvicola terrestris Linnaeus, 1758) (MacDonald et al. 2002) and synchrony between the fluctuations of mink and muskrat populations seems to occur in North America, with mink populations showing clear demographic delays with regard to muskrats (Haydon et al. 2001, Viljugrein et al. 2001).

Wild pig (Sus scrofa Linnaeus, 1758)

Current situation: the wild pig can be found both on human inhabited islands (e.g., Isla Navarino) as on uninhabited ones (e.g., Isla Hoste) (Anderson et al. 2006b).

Effects on Tierra del Fuego: no available information.

Potential effects: the wild pig is considered an ecosystem engineer since it modifies its habitat significantly, destroying surrounding physical structures (Crooks 2002). In fact, it is considered the main agent of soil disturbance in some of the areas it has invaded (e.g., Kotanen 1995). Its most disrupting activity is a result of its digging and rooting on the soil while searching for food (Cushman et al. 2004). The diet is variable and can range from roots to small animals (Baron 1982). Due to its foraging activity, biomass and richness of native and exotic vegetal species are altered (Cushman et al. 2004). Instances of almost total loss of the herbaceous layer in the understory have been recorded (Bratton 1975). From central to southern Chile, the diet of pig is highly vegetarian, including native plants suchs as Gunnera tinctoria ((Molina) Mirbel) and Blechnum chilense ((Kauf.) Mett.), which can also be found in TDF. Other dietary components are fungi, native small mammals, amphibians, lizards and insects (Skewes et al. 2007).

The pig can also impact vegetation through its reproductive habits. These animals construct nests, preferably of herbaceous and shrubby material, but where these resources are scarce, the pig may use tree saplings that are snapped or uprooted causing significant tree damage and mortality (e.g., Ickes et al. 2005). Additionally, substantial reductions $(80 \%)$ in vegetal cover and litter layer thickness occur as a result of the activity of pigs, the latter apparently due to a faster decomposition rate caused by the mechanical action imparted upon the litter (Singer et al. 1984).
The action of pigs on soil negatively affects richness, density and biomass of microarthropods (Vtorov 1993). Regarding vertebrates, some small mammals disappear from sites invaded by pigs, affected by the changes on the vegetal cover (Singer et al. 1984).

\section{DISCUSSION}

Our review indicates that few of the potential impacts of the the invaders presently found on TDF have been verified for archipelago (Table 1 ). These results are surprising given the large number of invaders present, but even more so given their recognized potential to cause significant ecological impacts, both locally and worldwide. For example, Anderson et al. (2006b) mention the beaver, muskrat and mink as the three 'most potentially harmful' species of the area. Similarly, Vila et al. (1999) comment on how salmonids and beaver ponds might be affecting the native icthyofauna of TDF, a fauna that exists in a poor state of conservation (Habit et al. 2006). Chilla fox has also been mentioned as harmful, in this case to native bird fauna (Anderson et al. 2006b); however, there is only one study (Madsen et al. 2003) that delves into this issue and it does so in a very indirect way. Additionally, four of the nine invaders of the TDF archipelago (brown and rainbow trout, European rabbit and wild pig) are listed among the world's 100 worst invasive alien species (Lowe et al. 2000). These precedents, together with the scarce number of studies on the effects of most of these species on TDF and our review of the impacts on other geographic areas, make it unlikely that the lack of verified effects on TDF owes to the absence of significant impacts of these species on the archipelago.

The beaver is the only species for which several aspects of its activity on TDF have been specifically studied (Table 1). This is not surprising, given the magnitude of the impacts derived of its presence, by which it controls the availability of resources to other species (Jones et al. 1997). In spite of being the most studied invader, our review of its potential impacts shows that there is still a lack of information on some of the effects of this rodent, especially on those related to impacts on native aquatic biota, 
such as invertebrates and fish. The chilla fox also appears as one of the species relatively well studied, at least regarding potential impacts that can be discarded, such as competition for food with the native culpeo fox and control of rabbit populations.

It must be pointed out that we did not find any description of impacts at geneticevolutionary level of the invaders of TDF. This is probably because these kind of effects are usually less studied than those that occur at the population or community levels (Parker et al. 1999). However, it is important not to ignore the impact of invaders at this ecological level. Invaders may quickly adapt to their new environment, while native species can also show adaptative responses to the pressure exerted by invaders (Mooney \& Cleland 2001, Olden et al. 2004). In any case, evolutionary impacts must be considered, since ineffective management practices may arise when this aspect is overlooked (Ashley et al. 2003).

The ecological effects caused by an invasive species in other geographic areas cannot be directly assumed to be occurring on TDF. This is because the effect of an invasive species depends not only on its own characteristics, but also on those of the system it invades (Heger \& Trepl 2003). This has been confirmed for beavers in TDF, since its effect on the vegetation of the archipelago differ from those found in its natural habitat (Anderson et al. 2006a). Conversely, in some cases, similar invasive patterns may be found between different geographic areas, as is the case for the invasion of salmonids in Chile and New Zealand (Soto et al. 2006). On places like the TDF archipelago, where invaders are several and have been present for a long period of time, knowledge about the impacts generated by these species in other sites must be utilized, at least to orient investigation and management, as well as to evaluate the pros and cons of deliberate introductions of other exotic species.

\section{Future research}

Based on our review of the potential ecological effects of invasive vertebrate species of the TDF archipelago, we propose the following lines of research, needed in order to know what changes are occurring as a result of these invasions, and to evaluate which species and impacts require urgent management.

\section{Freshwater systems}

These systems deserve special attention since several of the invaders have, to some degree, potential and actual impacts on their chemical, physical and biotic components. In addition, its ichthyofauna is in an especially vulnerable state.

Actions are already being taken in order to evaluate the feasibility of erradicating beavers from TDF (N. Soto, personal communication), so research on the long-term effects of the activity of the species and possibilities of restoration are needed. We encouraged research on the effects of muskrats on aquatic vegetation and nutrient cycles. Finally, studying the impact of salmon on native fish fauna, and the direct and indirect effects of these two last invaders on aquatic insects, zooplankton and phytoplankton is also relevant. Whenever possible, we suggest that these aspects be studied in an integrated manner.

\section{Vegetation and soil}

Wild pigs and rabbits have the potential to significantly alter these two components. We recommend studying the impact of these species on vegetal regeneration processes, vegetal cover and soil erosion.

\section{Birds}

This group, especially ground nesting and solitary species, appears vulnerable to predation by minks and chilla foxes. We recommend studies that identify populations or groups of species that require urgent protection against these predators, as well as the most vulnerable habitats and life stages according to the specific predation strategy.

\section{Interactions between invaders}

When managing invaders, the possible role of one species in facilitating another invader or in controlling it must be taken into account. In the first case, managing the facilitator could indirectly help to manage another invasive species. An example could be managing muskrats to control the mink populations that 
feed on them. However, one must be careful that minks will not increase pressure on birds ones muskrats are gone. In the second case, management of the invader might release pressure of another invader, resulting in unwanted potentiation of the impacts of the benefited species. For example, if mink populations were intentionally reduced, it might result in growth in muskrat populations. We recommend that any management action taken on a species, is done considering the impact on interacting invaders. In the specific case of minks and muskrats, it seems that both invaders should be controlled simultaneously.

\section{Population density and distribution}

Parker et al. (1999) suggest that in order to better determine the impact of invasive species, three factors should be taken into account: their range, population density, and some measure of the species per capita impact. Our review mainly refers to the third point. However, making estimates on population density and distribution in addition to existing data, in order to determine the final impact, is highly advisable.

\section{Feral species}

Anderson et al. (2006b) mention the presence of cows (Bos taurus Linnaeus, 1758), horses (Equus caballus Linnaeus, 1758), cats (Felis silvestris Schreber, 1775) and $\operatorname{dogs}$ (Canis lupus Linnaeus, 1758) on Cape Horn and atributes important ecological impacts to some of these species. It would be of interest to determine whether these domestic animals exist independent from human populations in the rest of the TDF archipelago, their population distribution, as well as their ecological impacts.

Invasiveness of the Tierra del Fuego archipelago

Anderson et al. (2006b) suggested that the success of such a large number of invaders on TDF and the special vulnerability of groups like ground nesting birds would be related to the absence of large predators, one of the characteristics that seems to make islands more vulnerable to some invasions (Simberloff 1995). We encourage studies that delve into specific characteristics of invasive species or of the invaded habitat related to successful invasion processes (e.g., Allen 2006) This information will be especially relevant when new introductions are intended since most, if not all, vertebrate terrestrial invaders that can be found today on TDF were once intentionally introduced, however the goals motivating their introduction were never achieved in most cases, as is the case for beavers, minks, and chilla foxes (Jaksic \& Yañez 1983, Lizarralde 1993, Jaksic et al. 2002, Iriarte et al. 2005), yielding several unwanted or unexpected impacts instead. Future introductions should therefore be carefully evaluated, not only in ecological terms, but also for their economic and social impacts. The captive breeding of red deer (Cervus elaphus Linnaeus, 1758) on Isla Grande (Fondo de innovación agraria FIA, www.fia.cl) deserves some special concern since this species has a recognized invasive capacity (Lowe et al. 2000) and the potential to negatively impact native vegetation (Ramírez et al. 1981, Eldridge 1983, Veblen et al. 1992, Relva \& Veblen 1998, Husheer et al. 2003) and fauna (Eldridge 1983, Flueck 1996, Flueck 2003). In fact, it has already successfully invaded southern Chile and Argentina (Jaksic et al. 2002).

\section{ACKNOWLEDGEMENTS}

We are grateful to the authors who provided articles of difficult accessibility and to Anton Seimon for his help with the translation of this manuscript. This work was carried out as part of its first author's professional internship, and was possible thanks to the support provided by the Wildlife Conservation Society and the Karukinka Conservation Project on Tierra del Fuego.

\section{LITERATURE CITED}

ALLEN CR (2006) Predictors of introduction success in the south Florida avifauna. Biological Invasions 8: 491-500.

ALLIBONE RM (1999) Impoundment and introductions: their impacts on native fish of the upper Waipori River, New Zealand. Journal of The Royal Society of New Zealand 29: 291-299.

ANDERSON CS, CR GRIFFITH, AD ROSEMOND, R ROZZI \& O DOLLENZ (2006a) The effects of 
invasive North American beavers on riparian plant communities in Cape Horn, Chile: do exotic beavers engineer differently in sub-Antarctic ecosystems? Biological Conservation 128: 467-474.

ANDERSON CB, R ROZZI, JC TORRES-MURA, SS MACGEHEE, MF SHERRIFFS, E SCHUTTLERZ \& AD ROSEMOND (2006b) Exotic vertebrate fauna in the remote and pristine sub-Antarctic Cape Horn archipelago, Chile. Biodiversity and Conservation 15: 3295-3313.

ARNOLD TW \& EK FRITZELL (1987) Food habits of prairie mink during the waterfowl breeding season. Canadian Journal of Zoology 65: 2322-2324.

ASHLEY MV, MF WILLSON, ORW PERGAMS, DJ O'DOWD, SM GENDE \& JS BROWN (2003) Evolutionarily enlightened management. Biological Conservation 111: 115-123.

AUED MB, C CHEHEBAR, G PORRO, DW MACDONALD \& MH CASSINI (2003) Environmental correlates of the distribution of the southern river otter Lontra provocax at different ecological scales. Oryx 37: 413-421.

BARON J (1982) Effects of feral hogs (Sus scrofa) on the vegetation of Horn Island. American Midland Naturalist 107: 202-205

BAXTER CV, KD FAUSCH, M MURAKAMI \& PL CHAPMAN (2004) Fish invasion restructures stream and forest food webs by interrupting reciprocal prey subsidies. Ecology 85: 2656-2663.

BLANCO D, R MATUS, O BLANK, L BENEGAS, S GOLDFEDER, F MOSCHIONE \& S ZALBA (2001) Manual para la conservación del cauquén (canquén) colorado en Argentina y Chile. Wetlands International, Buenos Aires, Argentina. $25 \mathrm{pp}$. Available at: http://www.wetlands.org/ LatinAmerica/Sp/publication.aspx?ID $=249 \mathrm{c} 7 \mathrm{f04}$ 04c2-402d-81d9-734be00d1d99

BRATTON SP (1975) The effect of the European wild boar, Sus scrofa, on gray beech forest in the Great Smokey Mountains. Ecology 56: 1356-1366.

CLODE D \& DW MACDONALD (2002) Invasive predators and the conservation of island birds: the case of American mink Mustela vison and terns Sterna spp. in the Western Isles, Scotland. Bird Study 49: 118-123.

CONNORS LM, E KIVIAT, PM GROFFMAN \& RS OSTFELD (2000) Muskrat (Ondatra zibethicus) disturbance to vegetation and potential net nitrogen mineralization and nitrification rates in a freshwater tidal marsh. American Midland Naturalist 143: 5363.

CRAIK C (1997) Long-term effects of north American mink Mustela vison on seabirds in western Scotland. Bird Study 44: 303-309.

CROOKS JA (2002) Characterizing ecosystem-level consequences of biological invasions: the role of ecosystem engineers. Oikos 97: 153-166.

CUSHMAN JH, TA TIERNEY \& JM HINDS (2004) Variable effects of feral pig disturbance on native and exotic plants in a California grassland. Ecological Applications 14: 1746-1756.

CUSSAC V, S ORTUBAY, G IGLESIAS, D MILANO, ME LATTUCA, JP BARRIGA, M BATTINI \& M GROSS (2004) The distribution of South American galaxiid fishes: the role of biological traits and post-glacial history. Journal of Biogeography 31: 103-121.

DELIBES M, M CLAVERO, J PRENDA, M BLAZQUEZ \& P FERRERAS (2004) Potential impact of an exotic mammal on rocky intertidal communities of northwestern Spain. Biological Invasions 6: 213 219.

DE SZALAY FA \& W CASSIDY (2001) Effects of muskrat (Ondatra zibethicus) lodge construction on invertebrate communities in a Great Lakes coastal wetland. American Midland Naturalist 146: 300310 .

DUKES JS \& HA MOONEY (2004) Disruption of ecosystem processes in western North America by invasive species. Revista Chilena de Historia Natural 77: 411-437

DUNSTONE N \& JDS BIRKS (1987) The feeding ecology of mink (Mustela vison) in coastal habitat. Journa of Zoology 212: 69-83.

ELDRIDGE W (1983) Impacto ambiental, alimentación y conducta social del ciervo rojo y dama en el sur de Chile. Corporación Nacional Forestal (CONAF), Boletín Técnico (Chile) 9: 1-53.

FERRERAS P \& DW MACDONALD (1999) The impact of American mink Mustela vison on water birds in the upper Thames. The Journal of Applied Ecology 36: 701-708.

FERRIÉRE G, J CERDA \& R ROACH (1983) El conejo silvestre en Chile. Corporación Nacional Forestal (CONAF), Boletín Técnico (Chile) 8: 1-35.

FLECKER AS \& CR TOWNSEND (1994) Communitywide consequences of trout introduction in New Zealand streams. Ecological Applications 4: 798807

FLUECK WT (1996) Zwischenartichle beziehungen zwischen freilebenden guanaco (Lama guanicoe) und angesiedeltem rotwild (Cervus elaphus) in Argentinien. Zeitschrift Jagdwissenschaft 42: 1217.

FLUECK WT, JAN SMITH-FLUECK \& CM NAUMANN (2003) The current distribution of red deer (Cervus elaphus) in southern Latin America. European Journal of Wildlife Research 49: 112-119.

FRITTS TH \& GH RODDA (1998) The role of introduced species in the degradation of island ecosystems: a case history of Guam. Annual review of Ecology and Systematics 29: 113-140.

FUENTES ER, FM JAKSIC \& JA SIMONETTI (1983) European rabbits versus native rodents in central Chile: effects on shrub seedlings. Oecologia 58 . 411-414.

GLADE A (1988) Libro rojo de los vertebrados terrestres de Chile. Primera edición. Corporación Nacional Forestal (CONAF), Ministerio de Agricultura, Santiago, Chile. 67 pp.

GROVES CR (2003) Drafting a conservation blueprint, a practioner's guide to planning for biodiversity. Island Press, Washington, District of Columbia, USA. 457 pp.

HABIT E, DYER B \& I VILA (2006) Estado de conocimiento de los peces dulceacuícolas de Chile. Gayana (Chile) 70: 100-103

HAYDON DT, NC STENSETH, MS BOYCE \& PE GREENWOOD (2001) Phase coupling and synchrony in the spatiotemporal dynamics of muskrat and mink populations across Canada. Proceedings of the National Academy of Sciences USA 98: 13149-13154.

HEGER T \& L TREPL (2003) Predicting biological invasions. Biological Invasions 5: 313-321.

HURYN AD (1998) Ecosystem-level evidence for topdown and bottom-up control of production in a grassland stream system. Oecologia 115: 173-183.

HUSHEER SW, DA COOMES \& AW ROBERTSON (2003) Long-term influences of introduced deer on 
the composition and structure of New Zealand Nothofagus forests. Forest Ecology and Management 181: 99-117.

ICKES K, CJ PACIOREK \& SC THOMAS (2005) Impacts of nest construction by native pigs (Sus scrofa) on lowland Malasyan rain forest saplings. Ecology 86: $1540-1547$.

INE (2003) Censo 2002: síntesis de resultados. Instituto Nacional de Estadísticas, Comisión Nacional del XVII Censo de Población y Vivienda, Santiago, Chile. 50 pp.

IRIARTE JA, GA LOBOS \& FM JAKSIC (2005) Invasive vertebrate species in Chile and their control and monitoring by governmental agencies. Revista Chilena de Historia Natural 78: 143-154.

JAKSIC FM (1998) Vertebrate invaders and their ecological impacts in Chile. Biodiversity and Conservation 7: 1427-1445.

JAKSIC FM \& ER FUENTES (1980) Why are native herbs in the Chilean matorral more abundant beneath bushes: microclimate or grazing? The Journal of Ecology 68: 665-669.

JAKSIC FM \& JL YÁÑEZ (1983) Rabbit and fox introductions in Tierra del Fuego: history and assessment of the attempts at biological control of the rabbit infestation. Biological Conservation 26: 367-374.

JAKSIC FM, JL YÁÑEZ \& JR RAU (1983) Trophic relations of the southernmost populations of Dusicyon in Chile. Journal of Mammalogy 64: 693697.

JAKSIC FM, JA IRIARTE, JE JIMÉNEZ \& DR MARTÍNEZ (2002) Invaders without frontiers: cross-border invasions of exotic mammals. Biological Invasions 4: 157-173.

JONES CG, JH LAWTON \& M SHACHAK (1997) Positive and negative effects of organisms as physical ecosystem engineers. Ecology 78: 1946-1957.

KANGAS PC \& GL HANNAN (1985) Vegetation on muskrat mounds in a Michigan marsh. American Midland Naturalist 113: 392-396.

KOTANEN PM (1995) Responses of vegetation to a changing regime of disturbance: effects of feral pigs in a Californian coastal prairie. Ecography 18: 190-199.

KRAJICK K (2005) Winning the war against island invaders. Science 310: 1410-1413.

LEE CE (2002) Evolutionary genetics of invasive species Trends in Ecology and Evolution 17:386-391.

LIZARRALDE MS (1993) Current status of the introduced beaver (Castor canadensis) population in Tierra del Fuego, Argentina. Ambio 22: 351-358.

LIZARRALDE MS \& J ESCOBAR (2000) Mamíferos exóticos en la Tierra del Fuego. Ciencia Hoy (Argentina) 10: 52-63

LIZARRALDE M, G DEFERRARI, J ESCOBAR \& S ALVAREZ (1996) Nutrient dynamic alterations induced by beaver (Castor canadensis) in the southern beech forest (Nothofagus). Ecología Austral 6: 101-105.

LOWE S, M BROWNE, S BOUDJELAS \& M DE POORTER (2000) 100 of the world's worst invasive alien species. A selection from the Global Invasive Species Database. The Invasive Species Specialist Group (ISSG), World Conservation Union (IUCN). 12 pp.

LYNCH JJ, T O’NEIL \& DW LAY (1947) Management significance of damage by geese and muskrats to gulf coast marches. Journal of Wildlife Management 11: 50-76.
MACDONALD DW, VE SIDOROVICH, EI ANISOMOVA, NV SIDOROVICH \& PJ JOHNSON (2002) The impact of American mink Mustela vison and European mink Mustela lutreola on water voles Arvicola terrestris in Belarus. Ecography 25: 295-302.

MACK MC \& CM D'ANTONIO (1998) Impacts of biological invasions on disturbance regimes. Trends in Ecology and Evolution 13: 195-198.

MACK RN, D SIMBERLOFF, WM LONSDALE, H EVANS, M CLOUT \& F BAZZAZ (2000) Biotic invasions: Causes, epidemiology, global consequences and control. Ecological Applications 10: 689-710.

MADSEN J, R MATUS, O BLANK, L BENEGAS, G MATEAZZI \& DE BLANCO (2003) Population status of the ruddy-headed goose (Chloephaga rubidiceps) in Tierra del Fuego and mainland Patagonia (Chile and Argentina). Ornitología Neotropical 14: 15-28.

MARTÍNEZ-PASTUR G, V LENCINAS, J ESCOBAR, P QUIROGA, L MALMIERCA \& M LIZARRALDE (2006) Understory succession in Nothofagus forests in Tierra del Fuego (Argentina) affected by Castor canadensis. Applied Vegetation Science 9: 143154.

MARTINIC M (1998) La tierra de los fuegos. Municipalidad de Porvenir, Porvenir, Chile. 221 pp.

MCINTOSH AR \& CR TOWNSEND (1994) Interpopulation variation in mayfly antipredator tactics: differential effects of contrasting predatory fish. Ecology 75: 2078-2090.

MCKINSTRY MC, RR KARHU \& SH ANDERSON (1997) Use of active beaver, Castor canadensis, lodges by muskrat, Ondatra zibethicus, in Wyoming. Canadian Field-Naturalist 111: 310-311.

MCNAUGHT AS, DW SCHINDLER, BR PARKER, AJ PAUL, RS ANDERSON, DB DONALD \& M AGBETI (1999) Restoration of the food web of an alpine lake following fish stocking. Limnology and Oceanography 44: 127-136.

MEDINA G (1997) A comparison of the diet and distribution of southern river otter (Lutra provocax) and mink (Mustela vison) in southern Chile. Journal of Zoology 242: 291-297.

MITTERMEIER R, C MITTERMEIER , P ROBLES-GIL , J PILGRIM , G FONSECA, K BROOKS \& J KONSTANT (2002) Wilderness: Earth's last wild places. Conservation International, Washington, District of Columbia, USA. 573 pp.

MOONEY HA \& EE CLELAND (2001) The evolutionary impact of invasive species. Proceedings of the National Academy of Sciences USA 98: 5446-5451.

MOORE DM (1983) Flora of Tierra del Fuego. Anthony Nelson, England, Missouri Botanical Garden, USA. $369 \mathrm{pp}$.

MORITA K, TSU BOI JI \& H MATSUDA (2004) The impact of exotic trout on native charr in a Japanese stream. Journal of Applied Ecology 21: 962-972.

NAIMAN RJ, JM MELILLO \& JE HOBBIE (1986). Ecosystem alteration of boreal forest streams by beaver (Castor canadensis). Ecology 67: 12541269.

NAKANO S, S KITANO, K NAKAI \& KD FAUSCH (1998) Competitive interactions for foraging microhabitat among introduced brook chart, Salvelinus fontinalis, and native bull chart, $S$. confluentus, and westslope cutthroat trout, Oncorhynchus clarki lewisi, in a Montana stream. Environmental Biology of Fishes 52: 345-355. 
NORDSTRÖM M \& E KORPIMÄKI (2004) Effects of island isolation and feral mink removal on bird communities on small islands in the Baltic Sea. Journal of Applied Ecology 73: 424-433.

NORTH SG, DJ BULLOCK \& ME DULLOO (1994) Changes in the vegetation and reptile populations on Round Island, Mauritius, following eradication of rabbits. Biological Conservation 67: 21-28.

NUMMI P (1992) The importance of beaver ponds to waterfowl broods: an experiment and natural test. Annales Zoologici Fennici 29: 47-55.

OLDEN JD, NL POFF, MR DOUGLAS, ME DOUGLAS \& KD FAUSCH (2004) Ecological and evolutionary consequences of biotic homogenization. Trends in Ecology and Evolution 19: 18-24.

PARKER IM, D SIMBERLOFF, WM LONSDALE, K GOODELL, M WONHAM, PM KAREIVA, MH WILLIAMSON, B VON HOLLE, PB MAYLE, JE BYERS \& L GOLDWASSER (1999) Impact: toward a framework for understanding the ecological effects of invaders. Biological Invasions 1: 3-19.

PASCUAL M, P MACCHI, J URBANSKI, F MARCOS, C RIVA ROSSI, M NOVARA \& P DELL'ARCIPRETE (2002) Evaluating potential effects of exotic freshwater fish from incomplete species presence-absence data. Biological Invasions 4: 101-113.

PENCZAK T (1999) Impact of introduced brown trout on native fish communities in the Pilica river catchment (Poland). Environmental Biology of Fishes 54: 237-252.

PETERSON DP, KD FAUSCH \& GC WHITE (2004) Population ecology of an invasion: effects of brook trout on native cutthroat trout. Ecological Applications 14: 754-772.

RAMIREZ C, R GODOY, W ELDRIDGE \& N PACHECO (1981) Impacto ecológico del ciervo rojo sobre el bosque de olivillo en Osorno, Chile. Anales del Museo de Historia Natural (Chile) 14: 197-215.

RELVA MA \& TT VEBLEN (1998) Impacts of introduced large herbivores on Austrocedrus chilensis forest in northern Patagonia, Argentina. Forest Ecology and Management 108: 27-40.

ROZZI R \& M SHERRIFFS (2003) El visón (Mustela vison) un nuevo mamífero exótico para la isla Navarino. Anales del Instituto de la Patagonia (Chile) 31: 97-104

SCHLAEPFER, MA, PW SHERMAN, B BLOSSEY \& MC RUNGE (2005) Introduced species as evolutionary traps. Ecology Letters 8: 241-246.

SIELDFELD KW \& CC VENEGAS (1980) Poblamiento e impacto ambiental de Castor canadensis Kuhl en Isla Navarino, Chile. Anales del Instituto de la Patagonia (Chile) 11: 247-257.

SIMBERLOFF D (1995) Why do introduced species seem to devastate islands more than mainland areas? Pacific Science 49: 87-97.

SIMONETTI JA (1986) Human-induced dietary shift in Ducisyon culpaeus. Mammalia 50: 406-408.

SINGER FJ, WT SWANK \& EEC CLEBSCH (1984) Effects of wild pig rooting in a deciduous forest. Journal of Wildlife Management 48: 464-473.
SKEWES RO, FSCH GONZÁLEZ, L RUBILAR, OM QUEZADA, RR OLAVE, VR VARGAS \& AC ÁVILA (1999) Investigación, aprovechamiento y control del castor en islas Tierra del Fuego y Navarino. Servicio de Gobierno Regional XII Región, Magallanes y Antártica Chilena. 185 pp.

SKEWES O, F GONZÁLEZ, R OLAVE, A ÁVILA, V VARGAS, P PAULSEN, HE KÖNIG (2006) Abundance and distribution of American beaver, Castor canadensis (Kuhl 1820), in Tierra del Fuego and Navarino islands, Chile. European Journal of Wildlife Research 52: 292-296.

SKEWES O, F RODRÍGUEZ \& FM JAKSIC (2007) Ecología trófica del jabalí europeo (Sus scrofa) silvestre en Chile. Revista Chilena de Historia Natural 80: 295-307.

SMIRNOV VV \& T TRETYAKOV (1998) Changes in aquatic plant communities on the island of Valaam due to invasion by the muskrat Ondatra zibethicus L. (Rodentia, Mammalia). Biodiversity and Conservation 7: 673-690.

SOL D (2000) Are islands more susceptible to be invaded than continents? Birds say no. Ecography 23: 687692.

SOTO D, I ARISMENDI, J GONZÁLEZ, J SANZANA, F JARA, C JARA, E GUZMÁN \& A LARA (2006) Sur de Chile, país de truchas y salmones: patrones de invasión y amenazas para las especies nativas. Revista Chilena de Historia Natural 79: 97-117.

TOWNSEND CR (1996) Invasion biology and ecological impacts of brown trout Salmo trutta in New Zealand. Biological Conservation 78: 13-22.

VEBLEN TT, M MERMOZ, $C$ MARTIN \& $T$ KITZBERGER (1992) Ecological impacts of introduced animals in Nahuel Huapi National Park, Argentina. Conservation Biology 6: 71-83.

VERGARA P \& RP SCHLATTER (2004) Magellanic woodpecker (Campephilus magellanicus) abundance and foraging in Tierra del Fuego, Chile. Journal of Ornithology 145: 343-.351.

VILA I, L FUENTES \& M SAAVEDRA (1999) Ictiofauna en los sistemas límnicos de la Isla Grande, Tierra del Fuego, Chile. Revista Chilena de Historia Natural 72: 273-284.

VILJUGREIN H, OC LINGJÆRDE, N STENSETH \& M BOYCE (2001) Spatio-temporal patterns of mink and muskrat in Canada during a quarter century. Journal of Animal Ecology 70: 671-682.

VTOROV IP (1993) Feral pig removal: effects on soil microarthropods in a Hawaiian rain forest. Journal of Wildlife Management 57: 875-880.

WAINSCOTT VJ, C BARTLEY \& P KANGAS (1990) Effect of muskrat mounds on microbial density on plant litter. American Midland Naturalist 123: 399 401.

WILCOVE DS, D ROTHSTEIN, J DUBOW, A PHILLIPS \& E LOSOS (1998) Quantifying threats to imperiled species in the United States. BioScience 48: 607-609.

WILLIAMSON M \& A FITTER (1996) The varying success of invaders. Ecology 77: 1661-1666. 